
doi: https://doi.org/10.33369/jik.v4i3.12999

\title{
KEMAMPUAN MENULIS TEKS TANGGAPAN BERDASARKAN FILM PENDEK SISWA KELAS IX SMP NEGERI 13 KOTA BENGKULU
}

\author{
${ }^{1}$ Abellia Frensivitasari, ${ }^{2}$ Ria Ariesta, ${ }^{3}$ Rio Kurniawan \\ 1,2,3Program Studi Pendidikan Bahasa Indonesia Jurusan Pendidikan Bahasa dan \\ Seni FKIP Universitas Bengkulu
}

Abstrak

Korespondensi: abellia219@gmail.com

Tujuan penelitian ini untuk mendeskripsikan kemampuan menulis teks tanggapan berdasarkan film pendek siswa kelas IX SMP Negeri 13 Kota Bengkulu. Penelitian ini menggunakan metode deskriptif kuantitatif yang dilaksanakan di SMP Negeri 13 Kota Bengkulu pada tanggal 10 Maret 2020. Populasi dalam penelitian ini semua siswa kelas IX SMP Negeri 13 Kota Bengkulu yang berjumlah 149 siswa., dan sampel diambil sebanyak 50 siswa secara acak. Kemampuan menulis teks tanggapan ini dinilai dari tiga aspek, yaitu isi, struktur teks, dan kebahasaan. Teknik pengumpulan data menggunakan teknik tes berupa penugasan kepada siswa untuk menulis teks tanggapan berdasarkan film pendek. Teknik analisis data dalam penelitian ini yaitu statistik deskriptif. Hasil penelitian menunjukkan bahwa kemampuan menulis teks tanggapan berdasarkan film pendek siswa kelas IX SMP Negeri 13 Kota Bengkulu adalah 59,32 (cukup).

Kata kunci : kemampuan menulis, teks tanggapan, film pendek

\begin{abstract}
The purpose of this study was to describe the ability to write response texts based on short films of class IX students of SMP Negeri 13 Bengkulu City. This study used a quantitative descriptive method which was conducted at SMP Negeri 13 Bengkulu City on March 10, 2020. The population in this study were all class IX students of SMP Negeri 13 Bengkulu City, totaling 149 students, and samples were taken as many as 50 students randomly. The ability to write response texts is assessed from three aspects, namely content, text structure, and language. The data collection technique used a test technique in the form of assigning students to write response texts based on short films. The data analysis technique in this research is descriptive statistics. The results showed that the ability to write response texts based on short films of class IX students of SMP Negeri 13 Bengkulu City was 59.32 (sufficient). Suggestions for students are to write more to increase vocabulary and learn about General Guidelines for Indonesian Spelling.
\end{abstract}

Keywords: writing skills, response texts, short films

\section{PENDAHULUAN}

Menulis merupakan suatu bentuk komunikasi dua arah yang efektif untuk mengomunikasikan ide atau gagasan melalui bahasa tulis. Lawrence dalam Saddhono dan Slamet (2014:151) menyatakan bahwa menulis adalah mengomunikasikan apa dan bagaimana pikiran penulis. Pada saat menulis seseorang memerlukan banyak waktu untuk berpikir, menuangkan ide-idenya di atas kertas dengan cara mengembangkan topik, 
memilih kata-kata, membaca kembali apa yang ditulisnya, memikirkannya, mempertimbangkannya dan memperbaikinya.

Menurut Nurudin (2010:4) menulis juga dapat diartikan sebagai kegiatan yang dilakukan seseorang untuk menghasilkan tulisan. Orang yang melakukan kegiatan coret mencoret di tembok itu juga bisa dikatakan dia sedang menulis, dengan atau tanpa maksud dan perangkat tertentu. Di dunia pendidikan, menulis bukan hanya sekadar kegiatan coret-mencoret di tembok. Menulis membutuhkan kemampuan agar dapat menghasilkan tulisan yang baik dan bisa dipahami oleh orang lain. Kemampuan menulis mencakup kecakapan seseorang dalam mengomunikasikan ide, gagasan, pengalaman yang diungkapkan melalui tulisan. Siswa yang memiliki kemampuan menulis dengan baik akan mendapatkan kemudahan dalam menyampaikan informasi dalam banyak hal, misalnya dalam menjawab soal dan mengerjakan tugas lainnya, baik dalam bentuk paragraf, artikel, maupun teks laporan ilmiah.

Menulis merupakan salah satu aspek keterampilan berbahasa yang mempunyai arti dan peranan penting bagi siswa. Siswa yang memiliki kemampuan menulis dengan baik akan mendapatkan kemudahan dalam menyampaikan informasi dalam banyak hal, misalnya dalam menjawab soal dan mengerjakan tugas lainnya, baik dalam bentuk paragraf, artikel, teks laporan ilmiah, dan sebagainya.

Menulis adalah kegiatan untuk melahirkan pikiran atau perasaan. Hasil yang dilahirkan oleh pikiran atau perasaan dalam bentuk tulis disebut tulisan atau karya tulis. Karya tulis sebagai hasil pikiran atau perasaan dapat berupa khayalan dan dapat berupa kenyataan yang benar-benar terjadi (Susetyo (2009: 1). Dalam kegiatan menulis dibutuhkan kemampuan agar menghasilkan sebuah tulisan. Susetyo (2015:73-74) mengemukakan bahwa kemampuan menulis ialah kesanggupan seseorang dalam mengkomunikasikan ide, pikiran, penghayatan dan pengalamannya dengan menggunakan bahasa tulis.

Pada satuan pendidikan Sekolah Menengah Pertama, salah satu teks yang diajarkan dalam pembelajaran Bahasa Indonesia adalah teks tanggapan. Pada Kurikulum 2013 kelas IX semester ganjil teks tanggapan terdapat pada KD 3.7, 3.8, 4.7 dan 4.8. KD 3.7 berisi mengidentifikasi informasi berupa kritik, sanggahan, atau pujian dari teks tanggapan (lingkungan bidup, kondisi sosial, dan/atau keragaman budaya, dll) yang didengar dan/atau dibaca. KD 3.8 berisi menelaah struktur dan kebahasaan dari teks tanggapan (lingkungan hidup, kondisi sosial, dan/atau keragaman budaya, dll) berupa kritik, sanggahan, atau pujian yang didengar dan/atau dibaca. KD 4.7 berisi menyimpulkan isi teks tanggapan berupa kritik, sanggahan, atau pujian (mengenai lingkungan bidup, kondisi sosial dan/atau keragaman budaya) yang didengar dan dibaca, dan KD 4.8 berisi mengungkapkan kritik, sanggahan, atau pujian dalam bentuk teks tanggapan secara lisan dan/atau tulis dengan memperbatikan struktur dan kebahasaan.

Teks tanggapan adalah teks yang berisi pendapat yang berupa kritik, sanggahan, atau pujian terhadap lingkungan hidup, kondisi sosial, keragaman budaya, tentang peristiwa, fenomena, ucapan, dan perbuatan, atau tentang suatu karya orang lain (Kosasih dan Restuti, 2018:93).

Teks tanggapan memiliki fungsi yang cukup penting dalam kehidupan masyarakat. Teks ini akan mengakrabkan siswa dengan sikap apresiasi manakala menyaksikan kebaikan atau hal positif. Teks tanggapan dapat meningkatkan dan melatih siswa untuk bersikap kritis serta berpikir secara kritis. Dalam menulis teks tanggapan, siswa diminta untuk memberikan atau menyampaikan kritik terhadap fenomena alam 
maupun sosial yang berada di sekitarnya, sehingga siswa akan cepat tanggap terhadap suatu kejadian yang terjadi di sekitarnya. Ini tentu sikap yang sangat baik yang perlu terus kita kembangkan.

Struktur teks tanggapan terdiri atas bagian-bagian berikut: konteks, deskripsi, dan evaluasi (Kosasih dan Restuti, 2018:105). Tanggapan yang diberikan berupa persetujuan, pujian, ketidaksetujuan, dan kritik. Ketika menanggapi karya yang diciptakan orang lain, seperti puisi, cerpen, novel, dan film, maka tanggapan tersebut disampaikan dengan cara yang baik, sopan, dan bermartabat. Di dalam penelitian ini, siswa diminta untuk mendeskripsikan dan memberikan pendapat mengenai film yang telah ditontonnya, yaitu tentang kelebihan atau kekurangan dari film tersebut, serta memberikan dan menangkap pesan yang disampaikan dari film yang telah ia tonton agar bisa diterapkan dalam kehidupan sehari-hari.

Ada banyak sekali keistimewaan media film, beberapa diantaranya adalah film dapat menghadirkan pengaruh emosional yang kuat, film dapat mengilustrasikan kontras visual secara langsung, film dapat berkomunikasi dengan para penontonnya tanpa batas menjangkau, dan film dapat memotivasi penonton untuk membuat perubahan.

Penelitian yang relevan dengan penelitian ini pernah dilakukan oleh Oktarina Widarsih (2017) yang berjudul "Perbedaan Kemampuan Menulis Teks Tanggapan Kritis Siswa Kelas IX SMPN 3 Bengkulu Utara dengan Siswa Kelas IX SMPN 10 Bengkulu Utara". Kemampuan menulis teks tanggapan kritis pada siswa kelas IX SMPN 3 Bengkulu Utara yaitu rata-rata 59,48 dengan kategori cukup, sedangkan kemampuan menulis teks tanggapan kritis pada siswa kelas IX SMPN 10 Bengkulu Utara yaitu ratarata 62,68 dengan kategori baik. Objek yang ditanggapi dalam penelitian yang pernah dilakukan sebelumnya yaitu mengenai media sosial, fenomena sosial, dan penggunaan gadget.

\section{METODE}

Jenis penelitian ini adalah penelitian kuantitatif yang menggunakan metode penelitian deskriptif. Populasi dalam penelitian ini adalah seluruh siswa kelas IX di SMP Negeri 13 Kota Bengkulu tahun ajaran 2019/2020 dengan jumlah populasi sebanyak 149 siswa yang tersebar dalam lima kelas. Dimana siswa laki-laki berjumlah 78 orang, dan siswi perempuan berjumlah 71 orang. Sampel penelitian yang digunakan adalah sampel acak. Sampel yang akan diambil dari penelitian ini sebanyak 50 siswa. Dalam penelitian ini pengambilan sampel dilakukan menggunakan cara undian.

Teknik pengumpulan data yang digunakan dalam penelitian ini adalah teknik tes. Tes dalam penelitian ini berbentuk penugasan kepada siswa untuk menulis teks tanggapan berdasarkan film pendek yang telah ditayangkan. Film pendek yang ditanggapi siswa yaitu film pendek yang berjudul "Ketimpangan Sosial".

Setelah data terkumpul dari hasil pengumpulan data, maka langkah selanjutnya adalah analisis data. Analisis data yang dilakukan dalam penelitian ini berdasarkan rubrik penilaian yang telah dibuat yaitu isi, kelengkapan struktur, dan kebahasaan pada saat menulis teks tanggapan.

Data yang telah diperoleh dari tes kemampuan menulis teks tanggapan berdasarkan film pendek dianalisis dengan langkah sebagai berikut:

1. Membaca teks hasil tanggapan yang telah dibuat siswa

2. Memeriksa hasil teks tanggapan 
3. Memberikan skor pada aspek yang diperiksa

4. Menghitung rata-rata (mean)

Rumus :

$\mathrm{M}=\frac{\sum X}{N}$

Keterangan :

$\mathrm{M}=$ Nilai rata-rata

$\sum X=$ Jumlah Nilai Siswa

$\mathrm{N}=$ Jumlah Subjek

\section{Tabel Tolok Ukur Penilaian Kemampuan Menulis Teks Tanggapan \\ Berdasarkan Film Pendek}

\begin{tabular}{|c|c|}
\hline Tingkat Penguasaan & Predikat \\
\hline $86-100$ & Sangat Baik \\
\hline $71-85$ & Baik \\
\hline $56-70$ & Cukup \\
\hline $41-55$ & Kurang \\
\hline$\leq 40$ & Kurang Sekali \\
\hline
\end{tabular}

(Modifikasi dari Purwanto, 1984:103)

\section{HASIL DAN PEMBAHASAN}

\section{Hasil Penelitian}

Hasil penelitian ini merupakan data kemampuan menulis teks tanggapan berdasarkan film pendek pada siswa kelas IX SMA Negeri 13 Kota Bengkulu dengan jumlah 50 siswa sebagai sampel. Untuk melihat kemampuan menulis teks tanggapan berdasarkan film pendek siswa diuji dengan tiga aspek yaitu:

1. Kemampuan menulis teks tanggapan berdasarkan film pendek pada aspek isi.

2. Kemampuan menulis teks tanggapan berdasarkan film pendek pada aspek struktur teks.

3. Kemampuan menulis teks tanggapan berdasarkan film pendek pada aspek kebahasaan.

Dari hasil perhitungan yang diperoleh skor rata-rata kemampuan menulis teks tanggapan berdasarkan film pendek siswa kelas IX SMP Negeri 13 Kota Bengkulu 59,32. Skor tersebut bila dilihat dalam kualifikasi skala lima termasuk dalam kategori cukup karena terletak pada rentang nilai 56-70. Dengan demikian, kemampuan menulis teks tanggapan berdasarkan film pendek siswa kelas IX SMP Negeri 13 Kota Bengkulu termasuk dalam kategori cukup.

Hasil perhitungan kemampuan menulis teks tanggapan berdasarkan film pendek siswa kelas IX SMP Negeri 13 Kota Bengkulu jika dimasukkan dalam kualifikasi skala lima sebagai berikut.

Tabel Frekuensi Tingkat Kemampuan Menulis Teks Tanggapan Berdasarkan Film Pendek

\begin{tabular}{|c|c|c|}
\hline Tingkat Penguasaan & Frekuensi & Kategori \\
\hline $86-100$ & 1 & Sangat Baik \\
\hline $71-85$ & 6 & Baik \\
\hline
\end{tabular}




\begin{tabular}{|c|c|c|}
\hline $56-70$ & 25 & Cukup \\
\hline $41-45$ & 18 & Kurang \\
\hline$\leq 40$ & 0 & Sangat Kurang \\
\hline
\end{tabular}

Berdasarkan frekuensi tingkat kemampuan menulis teks tanggapan berdasarkan film pendek dapat digambarkan dalam diagram 4 sebagai berikut.

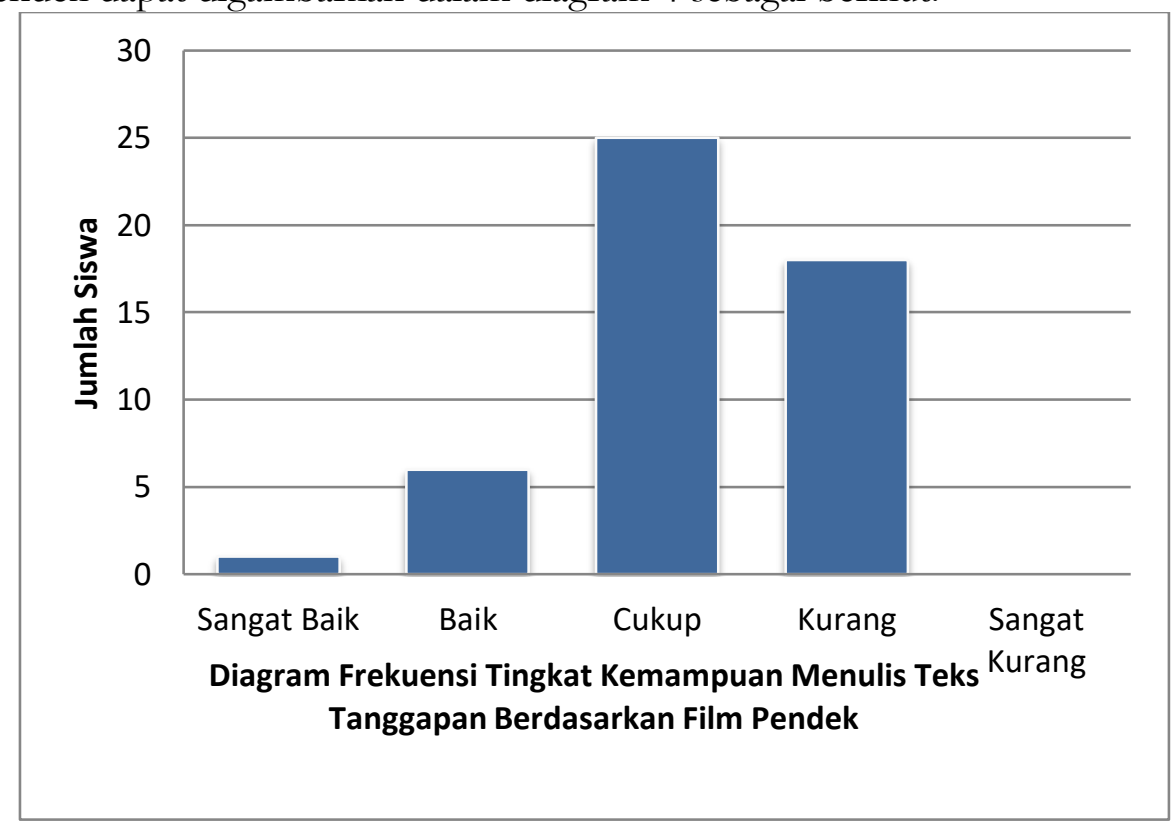

Berdasarkan hasil perhitungan frekuensi pada tabel dan diagram tersebut, dapat diketahui bahwa kemampuan menulis teks tanggapan berdasarkan film pendek siswa kelas IX SMP Negeri 13 Kota Bengkulu terbagi atas 1 siswa termasuk dalam kategori sangat baik, 6 siswa termasuk dalam kategori baik, 25 siswa termasuk dalam kategori cukup, 18 siswa termasuk dalam kategori kurang, dan 0 siswa termasuk dalam kategori sangat kurang.

\section{Pembahasan}

Dari hasil perhitungan menggunakan rumus yang telah ditetapkan diperoleh skor ratarata kemampuan menulis teks tanggapan berdasarkan film pendek "Ketimpangan Sosial" siswa kelas IX SMP Negeri 13 Kota Bengkulu sebesar 59,32. Skor tersebut bila dimasukkan dalam rentang skor skala lima maka berada pada rentang skor 56-70 dalam kategori cukup. Dengan demikian, kemampuan menulis teks tanggapan berdasarkan film pendek "Ketimpangan Sosial" siswa kelas IX SMP Negeri 13 Kota Bengkulu termasuk dalam kategori cukup.

Dari analisis data yang telah dilakukan pada kemampuan menulis teks tanggapan berdasarkan film pendek diketahui bahwa siswa kelas IX SMP Negeri 13 Kota Bengkulu sudah dapat menulis teks tanggapan berdasarkan film pendek "Ketimpangan Sosial" sesuai dengan strukturnya dan isi dari teks tanggapan juga sudah memuat mengenai film pendek yang ditayangkan. Akan tetapi, dalam menulis teks tanggapan penguasaan kata beberapa siswa masih terbatas yang mengakibatkan kalimat yang disampaikan menjadi kurang jelas dan sulit untuk dipahami. Selain itu, dalam menulis teks tanggapan masih 
banyak siswa yang salah dalam penulisan ejaannya (pemakaian huruf, penulisan kata, dan pemakaian tanda baca).

1. Kemampuan Menulis Teks Tanggapan Berdasarkan Film Pendek Aspek Isi

Isi terkait dengan ide atau gagasan yang dikembangkan dalam sebuah karangan, isi juga menyangkut kemampuan siswa dalam penguasaan topik tulisan. Dalam menulis teks tanggapan, isi tulisan harus berisi kritik, pujian, maupun saran terhadap lingkungan hidup, kondisi sosial, keragaman budaya, tentang peristiwa, fenomena, ucapan, dan perbuatan, atau tentang suatu karya orang lain (Kosasih dan Restuti, 2018: 93).

Kemampuan menulis teks tanggapan berdasarkan film pendek "Ketimpangan Sosial" siswa kelas IX SMP Negeri 13 Kota Bengkulu berdasarkan hasil analisis data yang telah dilakukan, isi tulisan siswa sudah memuat tentang film pendek "Ketimpangan Sosial" dan termasuk dalam kategori cukup. Dalam menulis teks tanggapan banyak siswa yang telah memberikan kritik, pujian, dan sarannya, serta beberapa siswa hanya memberikan kelebihan tentang film pendek yang telah ditayangkan. Dari 50 siswa yang dijadikan sampel, seluruhnya sudah menuliskan karangan berdasarkan film pendek "Ketimpangan Sosial", 28 siswa yang memberikan kritik, 42 siswa yang memberikan pujian, dan 28 siswa yang memberikan saran.

Teks tanggapan yang ditulis oleh siswa pada aspek isi kategori sangat baik sudah memuat tentang film pendek "Ketimpangan Sosial" secara lengkap dengan memberikan penilaian berupa kritikan, pujian, serta saran dalam menulis teks tanggapan yang mudah untuk dipahami.

Pasa aspek isi kategori baik, isi tulisan sudah memuat tentang film pendek "Ketimpangan Sosial" tetapi kurang lengkap hanya, serta penilaian yang diberikan sudah mencakup kritikan, pujian, serta saran dalam menulis teks tanggapan.

Pada aspek isi kategori cukup, isi tulisan sudah memuat tentang film pendek "Ketimpangan Sosial" tetapi kurang lengkap dan hanya gambaran secara umum saja. Isi tulisan sudah memuat penilaian berupa pujian kritikan dan saran dalam menulis teks tanggapan meskipun masih sederhana.

Pada aspek kategori kurang, isi tulisan sudah memuat tentang film pendek "Ketimpangan Sosial" tetapi kurang lengkap dan tidak terperinci hanya menggambarkan secara umum saja. Penilaian yang diberikan dalam menulis teks tanggapan juga kurang jelas dan tidak ada saran yang diberikan.

2. Kemampuan Menulis Teks Tanggapan Berdasarkan Film Pendek Aspek Struktur Teks

Kosasih dan Restuti (2018:105) menyebutkan bahwa struktur teks tanggapan terdiri atas konteks, deskripsi, dan penilaian. Konteks, berupa penyebutan tentang objek yang ditanggapi. Deskripsi, berisi tentang keadaan objek atau proses berlangsungnya kegiatan itu secara terperinci. Penilaian, berisi pendapat tentang objek itu, baik secara positif ataupun negatif, kelebihan, kekurangan dan saran.

Kemampuan menulis teks tanggapan berdasarkan film pendek "Ketimpangan Sosial" siswa SMP Negeri 13 Kota Bengkulu berdasarkan hasil analisis data dari aspek struktur teks dapat diketahui bahwa siswa sudah dapat menuliskan teks tanggapan film pendek berdasarkan strukturnya dengan sistematis, yaitu konteks, deskripsi, penilaian, dan hanya ada 2 siswa yang struktur teksnya tidak lengkap karena tidak memberikan penilaian dalam menulis teks tanggapan. 
Teks tanggapan yang ditulis oleh siswa pada aspek struktur teks kategori sangat baik yaitu siswa sudah menuliskan struktur teks dengan lengkap dan tersusun secara sistematis. Struktur teks dimulai dengan konteks yang didalamnya berisi judul film, produser, tempat, dan durasi film. Selanjutnya pada bagian deskripsi dijelaskan mengenai keadaan yang sedang terjadi secara keseluruhan dengan jelas meskipun tidak terlalu detail. Kemudian dilanjutkan dengan penilaian yang meliputi kekurangan dan kelebihan beserta saran dari penulis yang diungkapkan secara singkat dan detail.

Pada aspek struktur teks kategori baik, siswa sudah menuliskan struktur teks lengkap dan tersusun secara sistematis. Struktur teks dimulai dengan konteks, lalu dilanjutkan dengan deskripsi yang menjelaskan mengenai keadaan yang terjadi di film yang telah ditonton tetapi tidak menyeluruh. Pada bagian penilaian juga memuat mengenai kelebihan, kekurangan, dan saran meskipun masih sederhana penjelasannya.

Pada aspek struktur teks kategori cukup, siswa sudah menuliskan struktur teks dengan lengkap dan tersusun secara sistematis. Struktur teks dimulai dengan konteks, deskripsi, dan penilaian. Pada aspek struktur teks kategori kurang, struktur teks yang ditulis siswa tidak lengkap tetapi tersusun secara sistematis. Struktur teks dimulai dengan konteks yang didalamnya berisi waktu, lokasi, dan sutradara.. Pada bagian deskripsi memuat tentang film "Ketimpangan Sosial" tetapi tidak lengkap dan masih sangat sederhana dalam menjelaskannya, serta tidak ada penilaian yang diberikan dalam menulis teks tanggapan

3. Kemampuan Menulis Teks Tanggapan Berdasarkan Film Pendek Aspek Kebahasaan Ejaan adalah seperangkat aturan tentang cara menuliskan bahasa dengan menggunakan huruf, kata, dan tanda baca sebagai sarannya (dalam Satata dkk. 2012:162). Pilihan kata (diksi) pada dasarnya adalah hasil dari upaya memilih kata tertentu untuk dipakai dalam kalimat, alinea, atau wacana (dalam Satata dkk. 2012:115). Pilihan kata yang tepat dan sesuai akan membentuk kalimat yang efektif.

Kemampuan menulis teks tanggapan berdasarkan film pendek "Ketimpangan Sosial" siswa SMP Negeri 13 Kota Bengkulu berdasarkan hasil analisis data dari aspek kebahasaan dapat diketahui bahwa masih banyak siswa yang penguasaan katanya rendah dan terbatas, yang mengakibatkan kalimat yang ditulis menjadi tidak efektif dan maknanya jadi membingungkan. Selain itu, masih banyak siswa yang salah dalam penulisan ejaan, yaitu kesalahan dalam pemakaian huruf, penulisan kata, dan pemakaian tanda baca. Kesalahan yang paling banyak terletak pada penggunaan huruf kapital dan tanda baca. Contohnya siswa yang menggunakan huruf kapital di setiap awal kata, tidak menggunakan huruf kapital di awal kalimat baru, tidak menuliskan tanda baca titik di akhir kalimat, serta siswa salah menuliskan tanda baca yaitu antara tanda titik dan tanda koma.

Teks tanggapan yang ditulis oleh siswa dalam aspek kebahasaan tidak ada yang mencakup kategori sangat baik, karena masih ada penulisan ejaan yang salah. Pada kategori baik, siswa sudah menuliskan kalimat dengan jelas dan mudah dipahami serta terdapat beberapa kesalahan dalam penulisan ejaan. Pada aspek kebahasaan kategori cukup, kalimat yang diungkapkan masih banyak yang tidak nyambung dengan kalimat selanjutnya, penggunaan kata masih kadang salah tetapi masih bisa dipahami serta banyak kesalahan dalam penulisan ejaan. Pada aspek kebahasaan kategori kurang, kalimat yang diungkapkan masih kurang jelas dan banyak kalimat yang tidak efektif sehingga maknanya sulit untuk dipahami, serta banyak kesalahan dalam penulisan ejaan. 


\section{PENUTUP}

Berdasarkan hasil penelitian dan pembahasan, dapat disimpulkan bahwa kemampuan menulis teks tanggapan berdasarkan film pendek siswa kelas IX SMP Negeri 13 Kota Bengkulu cukup. Hal ini sesuai skor rata-rata akhir yang diperoleh 59,32 yaitu 1 siswa termasuk dalam kategori sangat baik, 6 siswa termasuk dalam kategori baik, 25 siswa termasuk dalam kategori cukup, 18 siswa termasuk dalam kategori kurang, dan 0 siswa termasuk dalam kategori sangat kurang.

Berdasarkan hasil penelitian yang dilakukan, penulis menyampaikan beberapa saran yang berkaitan dengan penelitian ini, sebagai berikut:

1. Hendaknya siswa lebih banyak menulis untuk menambah kosa kata dan lebih belajar mengenai Pedoman Umum Ejaan Bahasa Indonesia yang meliputi pemakaian huruf, penulisan kata, dan pemakaian tanda baca.

2. Meningkatkan mutu pembelajaran di kelas khususnya dalam pembelajaran teks tanggapan

\section{DAFTAR PUSTAKA}

Kosasih, Engkos dan Restuti. 2018. Bahasa Indonesia. Jakarta: Erlangga

Nugriyantoro, Burhan. 2016. Penilaian Pembelajaran Bahasa Berbasis Kompetensi. Yogyakarta: BPFE.

Nurudin. 2010. Dasar-Dasar Penulisan. Malang: UMM Press.

Purwanto, Ngalim. 1984. Prinsip-prinsip dan Teknik Evaluasi Pengajaran. Bandung: PT Remaja Rosdakarya.

Saddhono, Kundharu dan Slamet. 2014. Pembelajaran Keterampilan Berbahasa Indonesia; Teori dan Aplikasi Edisi 2. Yogyakarta: Graha Ilmu.

Susetyo. 2009. Menulis Akademik. Bengkulu: Penerbitan FKIP Universitas Bengkulu.

Susetyo. 2015. Penelitian Kuantitatif dan Penelitian Kualitatif Pengajaran Babasa dan Sastra Indonesia. Bengkulu: Universitas Bengkulu. 